\title{
Effect of Schinus molle and Schinus terebinthifolius Extracts on Sweet Pea Damping-off
}

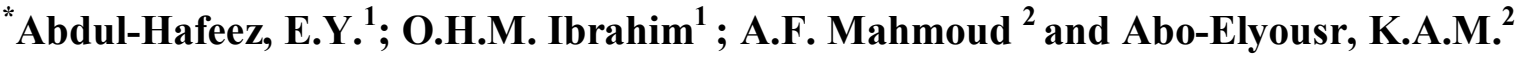

${ }^{1}$ Ornamental Plants and Landscape Gardening Dept., Fac. Agric., Assiut Univ., Egypt

${ }^{2}$ Plant Pathology Department, Faculty of Agriculture, Assiut University, Egypt

*Corresponding author: Essam.abdul-hafeez@agr.au.edu.eg

Received on: 8/3/2016

Accepted for publication on: 13/ 3/2016

\begin{abstract}
The potential efficiency of leaf and stem extracts of Schinus molle and Schinus terebinthifolius against Fusarium solani in addition to the phytochemical screening of both species was studied. Extracts were prepared using different solvents (water, ethanol, methanol and acetone). Fusarium solani was isolated and identified from naturally diseased sweet pea (Lathyrus odoratus) plants. According to the pathogenicity tests, the highest pathogenic isolate was used to test the antifungal activity of each extracts with different concentrations on mycelial growth of $F$. solani in vitro. The effect differed according to the extract type and concentration. The potential antifungal activity of ethanol extracts appeared highly significant when used with leaves, regardless of plant species, whereas acetone was effective when used with stems. The highest reduction of $F$. solani growth was obtained by ethanol and aqueous extracts of $S$. terebinthifolius leaves, ethanol extract of $S$. molle leaves, acetone extract of both $S$. molle and $S$. terebinthifolius stems, respectively. Effect of extracts at $64 \mathrm{mg} / \mathrm{ml}$ on dampingoff incidence of artificially infected $L$. odoratus under greenhouse conditions was studied as well. The highest reduction of the disease was achieved by leaf extracts of $S$. terebinthifolius followed by $S$. molle. These results were attributed to the presence of alkaloid, phenolics, flavonoids, and tannins in leaves and stems of both plant species as revealed by the phytochemical screening. Significant negative correlation was detected between in vitro inhibition percentage of $F$. solani and the field incidence of damping-off in $L$. odoratus plants. These results suggest that extracts from $S$. molle and $S$. terebenthefolius, especially ethanol leaf extracts and acetone stem extracts, are promising naturally derived antifungal agents for $F$. solani and other plant pathogenic fungi.
\end{abstract}

Keywords: Lathyrus odoratus, Fusarium solani, pepper tree, solvent extracts

\section{Introduction}

The sweet pea (Lathyrus odoratus L.) belongs to Leguminosae family and it is popular for cultivation in many places all over the world including Egypt. It is available with wide range of flower colors and consequently high commercial demand as there are reports of commercial sweet pea cut flower production however without accurate statistics for the production worldwide (Nakamura et al., 2008 and references therein). Production of sweet pea and other Leguminosae family is highly affected by damping-off and wilt disease caused by several soil borne 
fungi including Rhizoctonia solani (Kühn) and Fusarium solani, respectively (Burnchara and Camacho, 2000; El-Mougy, 2001). Taubenhaus (1914) claimed that Fusarium wilt or root rot of sweet pea was caused by a new species to which they tentatively gave the name Fusarium lathyri.

Controlling plant diseases depends mainly on using synthetic fungicides as excessive use of fungicides in agriculture system led to environmental pollution and hazardous of human health (Tepe et al., 2004). Recently, considerable attention has been focused on the potential use of plant extracts as natural and safe alternatives instead of synthetic fungicides. Many potent and powerful antimicrobial agents have been derived from Cassia fistula showing high antifungal activity against Fusarium solani, F. oxysporum and Rhizoctonia solani (Ibrahim et al., 2015).

Schinus (pepper tree) belongs to family Anacardiaceae, with the main species are Schinus terebinthifolius Roddi and $S$. molle. L. Both species have been introduced from South America to most of the tropical and subtropical areas of the world and to the Mediterranean (Taylor, 2005). Several previous studies indicated that extracts of different parts of these plants have high medicinal value and have been used in folk medicine for a long time to treat many illnesses. A few reports are available on effect of plant extracts against plant pathogens as stated by Rhouma et al. (2009), they compared leaf extracts from $S$. terebenthifolius and $S$. molle against some plant pathogens; Agrobacterium tumefaciens, Pseudomonas savastanoi pv. savastanoi, Fusarium solani and Rhizoctonia solani. They found that aqueous and methanolic extracts showed a high level of antifungal and antibacterial activity compared to hexane and ethanolic ones, which positively correlated with total phenol contents of the extracts.

Several strategies were used for controlling such diseases including chemical control, cultural practices, biological control and plant extracts (Mezeal, 2014 and references therein). Therefore our current work to determine the potential efficiency of leaf and stem extracts of both $S$. molle and $S$. terebinthifolius using different solvents against Fusarium growth in vitro and in vivo as seed pre-sowing treatment against damping-off disease of sweet pea plants under greenhouse conditions.

\section{Materials and Methods}

\section{Isolation of the pathogen}

Diseased Lathyrus odoratus plants showing symptoms of damping off were collected from the Floriculture Experimental Farm, Faculty of Agriculture, Assiut University, Egypt, during 2012 season. Small pieces of roots with lesion were disinfested in $0.5 \% \mathrm{NaOCl}$ for $1 \mathrm{~min}$. Rinsed several times with sterilized water and dried with sterilized filter papers. The surface-sterilized plant pieces were placed on Petri dishes containing Potato Dextrose Agar medium (PDA) and incubated 7 days at $27^{\circ} \mathrm{C}$. After 7 days of incubation, the developed fungal colonies were purified by hyphal tip technique. The obtained fungal isolates were identified according to their cultural and microscopical characteristics as described by Barnett and Hunter (1986). Subcultures of the obtained isolates were 
kept on PDA slants and stored at $5^{\circ} \mathrm{C}$ for further studies.

\section{Pathogenicity tests}

Pathogenic capabilities of 3 isolates were tested on L. odoratus seedlings under greenhouse conditions during 2012 season. Inocula of the tested isolates were prepared by growing in sterilized glass bottles $(500 \mathrm{ml})$ containing barley medium (150 g sorghum seeds, $50 \mathrm{~g}$ clean sand, $4 \mathrm{~g}$ glucose, and $200 \mathrm{ml}$ water), autoclaved in two consecutive days and incubated at $25^{\circ} \mathrm{C}$ for 15 days. Sterilized pots $(20 \mathrm{~cm}$ in diameter $)$ were filled with sterilized clay soil and then infested with each isolate at the rate of $1 \%$. Each pot was planted with 10 sterilized seeds. Five pots were considered for each treatment as replicates, whereas untreated pots with pathogens were used as control (Abo-Elyousr et al., 2009). Emergence of $L$. odoratus seedlings at 20 days from planting was estimated for damping-off, pre-emergence damping-off (\%) was calculated based on the number of non-emerged seeds in relation to the number of sown seeds.

\section{Plant materials}

Leaf and stem samples were collected from the two tested species; Schinus molle and S. terebinthifolius during 2013 season. The trees were locally grown at the Floriculture Experimental Farm, Faculty of Agriculture, Assiut University, Egypt. The plants were authenticated by senior colleagues of Department of Ornamental Plants and Landscape Gardening.

\section{Extract preparation}

Dry powder of leaves and stems $(200 \mathrm{~g})$ from each of $S$. molle and $S$. terebinthifolius was macerated each alone in 2 liter of four solvents; distilled water and $40 \%$ of ethanol, methanol and acetone for $48 \mathrm{~h}$ at room temperature under constant shaking. The macerates were homogenized for $15 \mathrm{~min}$. and then filtered with watmann filter paper under vacuum filtration. The residues were farther macerated twice in the same manner. The filtrates obtained were mixed and the solvents were evaporated using rotary evaporator (Hidolph VV2000). The residues were left in porcelain dishes to dryness. Dried extracts were weighed and calculated relative to plant sample fresh weight. Total dried extracts were kept in tightly stoppered bottles in refrigerator $2-4^{\circ} \mathrm{c}$.

\section{Phytochemical screening}

Dry powder of leaves and stems of both $S$. molle and S. terebinthifolius was subjected to qualitative phytochemical screening for identification of various classes of active constituents according to the methods described by Evans (2002) and Khandelwal (2001).

Test for the presence of saponins: $1 \mathrm{mg}$ of each extract was dissolved in distilled water $(1 \mathrm{ml})$ and vortexed. The presence of saponins was verified by the formation of abundant and persistent foam.

Test for the presence of phenols and tannins: three drops of ferric chloride $(10 \%$, in ethanol) were added to $2 \mathrm{ml}$ of each extract (1 $\mathrm{mg} / \mathrm{ml}$, in ethanol). The presence of phenols was confirmed when color of the extracts varied between blue and red was. The formation of a dark blue precipitate indicates the presence of hydrolysable tannins and the forma- 
tion of a green precipitate the presence of condensed tannins.

Test for the presence of flavonoids: alkaline reagent test was used where extracts were treated with few drops of sodium hydroxide solution. Formation of intense yellow color becoming colorless upon addition of dilute acid indicates the presence of flavonoids.

Test for the presence of steroids and free tetracyclic triterpenes: $1 \mathrm{mg}$ of each extract was dissolved in $1 \mathrm{ml}$ of chloroform. Then, $1 \mathrm{ml}$ of acetic anhydride was added and 3 drops of concentrated sulfuric acid were slowly added. The emergence of evanescent blue color then permanent green was indicative of the presence of free steroids and a brownish red for free pentacyclic triterpenes.

Test for the presence of alkaloids: For estimation of alkaloids, 0.5 to 0.6 $\mathrm{g}$ of each extract was mixed in $8 \mathrm{ml}$ of $1 \% \mathrm{HCl}$, warmed and filtered. $2 \mathrm{ml}$ of the filtrate were treated separately with both reagents of Maeyer's and Dragendorff's. Then, it was observed whether the alkaloids were present or absent in the turbidity or precipitate formation.

\section{Antifungal activity assay in vitro}

Laboratory works were directed to study the antifungal activities of sixteen plant extracts on linear growth of $F$. solani according to the method described by Mecteau et al. (2002) with some modifications. Each crude Extract solution was filtered through a $0.22 \mu \mathrm{m}$ sterile filter (PES Syringe filter). Each plant extract was added singly to conical flasks $(250 \mathrm{ml})$ contenting Potato dextrose agar (PDA) medium to get concentrations of 64,32 and 16 $\mathrm{mg} / \mathrm{ml}$. Non treated PDA medium with extract was used as control. Each flask purred in Petri dishes (9 $\mathrm{cm}$ in diameter) and inoculated in the center with disks $(5 \mathrm{~mm})$ of $F$. solani, 7 days old culture. Four replicates were used for each treatment. Cycloheximide with concentration of 0.5 $\mathrm{mg} / \mathrm{ml}$ was used as a positive control. Plates were incubated at $25 \pm 2^{\circ} \mathrm{C}$. Linear growth was measured using a ruler, when $F$. solani growth filled up control plates. The percentage of inhibition in fungus growth was calculated as follow:

Inhibition $\%=\frac{\mathrm{A}-\mathrm{B}}{\mathrm{A}} \times 100$

Where: $A=$ colony diameter of control; $\mathrm{B}=$ colony diameter of treatment.

Testing of extracts against the pathogen under greenhouse conditions

Two experiments were carried out under greenhouse conditions in seasons 2013/2014 and 2014/2015 seasons. Pots $(20 \mathrm{~cm}$. in diam.) were sterilized by immersing in 5\% formalin solution for $10 \mathrm{~min}$. and left to dry in open air. Extracts treatments at $64 \mathrm{mg} / \mathrm{ml}$ was applied as seed treatment. Greenhouse experiments were repeated twice, and pathogenic isolate no 2 was prepared as mentioned before in pathogenicity tests and mixed with sterilized soil in rate of $2 \%$ of the soil weight in the sterilized pots. The pots were left for one week, watered and mixed thoroughly to ensure even distribution of infested fungi. Each pot was planted with 10 sterilized seeds. Sterilized seeds were immersed in each extract at $64 \mathrm{mg} / \mathrm{ml}$ and left to dry. Untreated seeds with extracts were used as control. Each 
treatment was replicated four times. Percentage of disease was recorded after 20 days; results were calculated as previously mentioned in pathogenicity tests.

\section{Statistical analysis}

The results were analyzed using ANOVA test and the means differences were regarded as significant using LSD test at 5\% level of probability. The obtained antibacterial results were stated in as mean \pm SD for three replicates according to Gomez and Gomez (1984).

\section{Results}

\section{Identification of the causal patho- gen}

Three fungal isolates were obtained from naturally diseased Lathyruso doratus showing damping off symptoms and identified as $F$. solani, based on the morphological characteristics (Barnett and Hunter, 1986).

\section{Pathogenicity tests}

Results in Table 1 indicate that all the tested isolates of $F$. solani were able to infect $L$. odoratus plants causing typical symptoms of damping-off with different degrees of disease percentage of damping-off. Data indicate that isolate no 2 caused the highest disease percentage of damping-off followed by other isolates. On the basis of these results, isolate 2 was used in the following experiments.

Table 1. Pathogenicity tests of three isolates of Fusarium solani (Fs) on Lathyrus odoratus plants.

\begin{tabular}{|c|c|}
\hline Isolates No. & \% damping off \\
\hline Rs 1 & $20 \mathrm{~b}$ \\
\hline Rs 2 & $40 \mathrm{a}$ \\
\hline Rs 3 & $20 \mathrm{~b}$ \\
\hline
\end{tabular}

The values in the column followed by same letter are not significantly different according to ANOVA (L.S.D. $p=0.05$ )

\section{Phytochemical screening}

The results of the phytochemical analysis presented in Table 2 show the presence of alkaloids, phenolics, flavonoids, and tannins in leaves and stems of both $S$. molle and
$S$. terebenthefolius. On the other hand, all extracts were tested negative for saponins, steroids and triterpenoids except stems of $S$. terebenthefolius which were found positive for steroids and triterpenoids. 
Table 2. Preliminary phytochemical screening of leaves and stems of both $S$. molle and $S$. terebenthefolius

\begin{tabular}{|l|c|c|c|c|}
\hline \multirow{2}{*}{ Phytochemical constituents } & \multicolumn{2}{c|}{ S. molle } & \multicolumn{2}{c|}{ S. terebenthefolius } \\
\cline { 2 - 5 } & Leaves & Stems & Leaves & Stems \\
\hline Alkaloids & + & + & + & + \\
\hline Phenolics & + & + & + & + \\
\hline Flavonoids & + & + & + & + \\
\hline Saponins & - & - & - & - \\
\hline Steroids and Triterpenoids & - & - & - & + \\
\hline Tannins & + & + & + & + \\
\hline
\end{tabular}

\section{Antifungal activity assay}

The activities of different concentrations of sixteen plant extracts on mycelial growth of $F$. solani were tested in vitro. Table 3 illustrated that the addition of different concentrations of each plant extracts separately to the media affected significantly the mycelial growth of $F$. solani. The effect differed according to the tested extract and the concentration. The highest reduction of Fusarium growth was noticed at concentration of 64 $\mathrm{mg} / \mathrm{ml}$ when the media were amended with ethanol and aqueous extracts of $S$. terebinthifolius leaves, ethanol extract of $S$. molle leaves, acetone extract of both $S$. molle $S$. terebinthifolius stems, respectively. Methanol gave moderate to high results with both leaves and stems of both species. Moreover, the plant extracts inhibited significantly the growth of $F$. solani at all tested concentrations compared to the control. Mycelial growth reduction was increased depending on the concentration reaching its maximum effect at concentration of 64 $\mathrm{mg} / \mathrm{ml}$. On the other hand, aqueous extract of $S$. molle stems and acetone extract of $S$. molle leaves gave the least reduction on $F$. solani with the three tested concentrations, respectively. The other plant extracts showed intermediate effects.

Effect of extracts on damping-off incidence under artificial infection under greenhouse conditions
Based on in vitro screening, the best concentration of each extract was selected to follow up their effects under greenhouse conditions against the pathogen. Seed treatments with each extract at $64 \mathrm{mg} / \mathrm{ml}$ significantly reduced the damping-off incidence of L. odoratus compared with control plants under artificial infection with $F$. solani under greenhouse conditions in both tested seasons. The highest reduction of the disease was achieved by leaf extracts of $S$. terebinthifolius followed by $S$. molle then stems of $S$. terebinthifolius followed by $S$. molle as shown in Table 4 . Seeds treated with leaf ethanol extract of $S$. terebinthifolius gave the best reduction of the disease in both seasons, while seeds treated with stems acetone extracts of $S$. terebinthifolius and $S$. molle showed the lowest percentage of damping-off compared with other solvents. Seeds treated with leaf methanol or aqueous extracts of $S$. molle and S. terebinthifolius showed moderate effect of damping-off percentage. Whereas, the highest percentage of the disease incidence was observed when seeds were treated with aqueous stem extract of $S$. molle followed by $S$. terebinthifolius. No significance appeared on the disease between ethanol and methanol stem extracts of S. terebinthifolius, but ethanol stems extracts of $S$. molle showed lower percentage of damping-off than methanol stems extracts. Results in Fig 1 show a sig- 
nificant negative correlation at $\mathrm{p}<0.05$ between in vitro inhibition $\%$ of $F$. solani and damping-off $\%$ incidence of $L$. odoratus plants under artificial infection in greenhouse conditions during both tested seasons as affected by different extracts of both S. molle and S. terebinthifolius leaves and stems. The regression $\left(\mathrm{R}^{2}\right)$ reached 0.765 and 0.645 in the first and second seasons, respectively.

Table 3. Antifungal activities of sixteen plant extracts on radial growth of $\boldsymbol{F}$. solani in vitro

\begin{tabular}{|c|c|c|c|c|}
\hline Plant material & Solvent & $\begin{array}{c}\text { Concentration } \\
\mathrm{mg} / \mathrm{ml}\end{array}$ & $\begin{array}{l}\text { F. solani. colony } \\
\text { diameter in } \mathrm{cm}\end{array}$ & $\begin{array}{c}\text { Inhibition } \\
\% \\
\end{array}$ \\
\hline \multirow[t]{12}{*}{ S. molle leaves } & \multirow[t]{3}{*}{ Water } & 64 & $2.32 \mathrm{fg}$ & 74.16 \\
\hline & & 32 & $3.12 \mathrm{jkl}$ & 65.27 \\
\hline & & 16 & $3.57 \mathrm{no}$ & 60.27 \\
\hline & \multirow[t]{3}{*}{ Ethanol } & 64 & $1.57 \mathrm{bc}$ & 82.50 \\
\hline & & 32 & $1.82 \mathrm{~d}$ & 79.72 \\
\hline & & 16 & $2.62 \mathrm{~h}$ & 70.83 \\
\hline & \multirow[t]{3}{*}{ Methanol } & 64 & $2.12 \mathrm{ef}$ & 76.38 \\
\hline & & 32 & $3.55 \mathrm{no}$ & 60.55 \\
\hline & & 16 & $4.12 \mathrm{pq}$ & 54.16 \\
\hline & \multirow[t]{3}{*}{ Acetone } & 64 & 4.30 qrs & 52.22 \\
\hline & & 32 & $4.60 \mathrm{tu}$ & 48.88 \\
\hline & & 16 & $5.27 \mathrm{v}$ & 41.38 \\
\hline \multirow[t]{12}{*}{ S. molle stems } & \multirow[t]{3}{*}{ Water } & 64 & $4.47 \mathrm{stu}$ & 50.27 \\
\hline & & 32 & $4.60 \mathrm{tu}$ & 48.88 \\
\hline & & 16 & $5.12 \mathrm{v}$ & 43.05 \\
\hline & \multirow[t]{3}{*}{ Ethanol } & 64 & $2.87 \mathrm{i}$ & 68.05 \\
\hline & & 32 & $3.02 \mathrm{ijk}$ & 66.38 \\
\hline & & 16 & $4.25 \mathrm{qr}$ & 52.77 \\
\hline & \multirow[t]{3}{*}{ Methanol } & 64 & $3.42 \mathrm{mn}$ & 61.94 \\
\hline & & 32 & $4.17 \mathrm{q}$ & 53.61 \\
\hline & & 16 & $4.65 \mathrm{u}$ & 48.33 \\
\hline & \multirow[t]{3}{*}{ Acetone } & 64 & $1.85 \mathrm{~d}$ & 79.44 \\
\hline & & 32 & $2.47 \mathrm{gh}$ & 72.50 \\
\hline & & 16 & $3.42 \mathrm{mn}$ & 61.94 \\
\hline \multirow{12}{*}{$\begin{array}{l}\text { S. terebinthifolius } \\
\text { Leaves }\end{array}$} & \multirow[t]{3}{*}{ Water } & 64 & $1.50 \mathrm{ab}$ & 83.33 \\
\hline & & 32 & $1.75 \mathrm{~cd}$ & 80.55 \\
\hline & & 16 & $2.30 \mathrm{efg}$ & 74.44 \\
\hline & \multirow[t]{3}{*}{ Ethanol } & 64 & $1.32 \mathrm{a}$ & 85.27 \\
\hline & & 32 & $1.57 \mathrm{bc}$ & 82.50 \\
\hline & & 16 & $2.30 \mathrm{efg}$ & 74.44 \\
\hline & \multirow[t]{3}{*}{ Methanol } & 64 & $2.10 \mathrm{e}$ & 76.66 \\
\hline & & 32 & $2.97 \mathrm{ij}$ & 66.94 \\
\hline & & 16 & $4.17 \mathrm{q}$ & 53.61 \\
\hline & \multirow[t]{3}{*}{ Acetone } & 64 & $3.17 \mathrm{jkl}$ & 64.72 \\
\hline & & 32 & $3.65 \mathrm{o}$ & 59.44 \\
\hline & & 16 & $4.40 \mathrm{rst}$ & 51.11 \\
\hline \multirow{12}{*}{$\begin{array}{l}\text { S. terebinthifolius } \\
\text { Stems }\end{array}$} & \multirow[t]{3}{*}{ Water } & 64 & $2.55 \mathrm{~h}$ & 71.66 \\
\hline & & 32 & $3.27 \mathrm{~lm}$ & 63.61 \\
\hline & & 16 & $4.40 \mathrm{rst}$ & 51.11 \\
\hline & \multirow[t]{3}{*}{ Ethanol } & 64 & $3.22 \mathrm{klm}$ & 64.16 \\
\hline & & 32 & $3.50 \mathrm{no}$ & 61.11 \\
\hline & & 16 & $3.95 \mathrm{p}$ & 56.11 \\
\hline & \multirow[t]{3}{*}{ Methanol } & 64 & $2.85 \mathrm{i}$ & 68.33 \\
\hline & & 32 & $3.17 \mathrm{jkl}$ & 64.72 \\
\hline & & 16 & $4.10 \mathrm{pq}$ & 54.44 \\
\hline & \multirow[t]{3}{*}{ Acetone } & 64 & $1.87 \mathrm{~d}$ & 79.16 \\
\hline & & 32 & $2.17 \mathrm{ef}$ & 75.83 \\
\hline & & 16 & $3.00 \mathrm{ij}$ & 66.66 \\
\hline \multicolumn{2}{|c|}{ Positive control (Cycloheximide) } & 0.5 & $1.40 \mathrm{VW}$ & $84.4 \%$ \\
\hline Control & & - & $9.00 \mathrm{w}$ & 0.0 \\
\hline LSD 0.05 & & & 0.20 & \\
\hline
\end{tabular}


Table 4. Effect of Schinus plant extracts with different solvents at $64 \mathrm{mg} / \mathrm{ml}$ on $F$. solani damping-off $(\%)$ of $L$. odoratus under greenhouse conditions during 2014 and 2015 seasons

\begin{tabular}{|c|c|c|c|}
\hline \multirow{2}{*}{ Plant material } & \multirow{2}{*}{ Solvent } & \multicolumn{2}{|c|}{ Damping off $(\%)$} \\
\hline & & 2014 & 2015 \\
\hline \multirow{5}{*}{$\begin{array}{l}\text { S. molle } \\
\text { leaves }\end{array}$} & Water & $41.6 \mathrm{~d}$ & $43.6 \mathrm{~d}$ \\
\hline & Ethanol & $24.4 \mathrm{~b}$ & $28.0 \mathrm{~b}$ \\
\hline & Methanol & $41.6 \mathrm{~d}$ & $40.0 \mathrm{c}$ \\
\hline & Acetone & $64.0 \mathrm{i}$ & $60.0 \mathrm{i}$ \\
\hline & Mean & $45.9 \mathrm{~B}$ & $42.9 \mathrm{~B}$ \\
\hline \multirow{5}{*}{$\begin{array}{l}\text { S. molle } \\
\text { stems }\end{array}$} & Water & $64.8 \mathrm{i}$ & $64.0 \mathrm{j}$ \\
\hline & Ethanol & $52.4 \mathrm{~g}$ & $52.0 \mathrm{~g}$ \\
\hline & Methanol & $55.6 \mathrm{~h}$ & $56.0 \mathrm{~h}$ \\
\hline & Acetone & $42.0 \mathrm{de}$ & $49.2 \mathrm{f}$ \\
\hline & Mean & $53.7 \mathrm{D}$ & $55.3 \mathrm{D}$ \\
\hline \multirow{5}{*}{$\begin{array}{l}\text { S. terebinthifolius } \\
\text { Leaves }\end{array}$} & Water & $42.2 \mathrm{de}$ & $49.2 \mathrm{f}$ \\
\hline & Ethanol & $22.0 \mathrm{a}$ & $20.0 \mathrm{a}$ \\
\hline & Methanol & $40.0 \mathrm{~cd}$ & $44.4 \mathrm{e}$ \\
\hline & Acetone & $52.0 \mathrm{~g}$ & $56.0 \mathrm{~h}$ \\
\hline & Mean & $40.8 \mathrm{~A}$ & $36.1 \mathrm{~A}$ \\
\hline \multirow{5}{*}{$\begin{array}{l}\text { S. terebinthifolius } \\
\text { Stems }\end{array}$} & Water & $56.0 \mathrm{~h}$ & $48.4 \mathrm{f}$ \\
\hline & Ethanol & $47.0 \mathrm{f}$ & $55.2 \mathrm{~h}$ \\
\hline & Methanol & $47.6 \mathrm{f}$ & $54.0 \mathrm{gh}$ \\
\hline & Acetone & $44.0 \mathrm{e}$ & $48.8 \mathrm{f}$ \\
\hline & Mean & $48.8 \mathrm{C}$ & $51.6 \mathrm{C}$ \\
\hline Control & & $80.0 \mathrm{jE}$ & $76.0 \mathrm{kE}$ \\
\hline
\end{tabular}

* Means within the same column followed by the small letters are not significantly different $(\mathrm{P} \leq 0.05)$ based on LSD; Means within the same column followed by the capital letters are not significantly different $(\mathrm{P} \leq 0.05)$ based on LSD
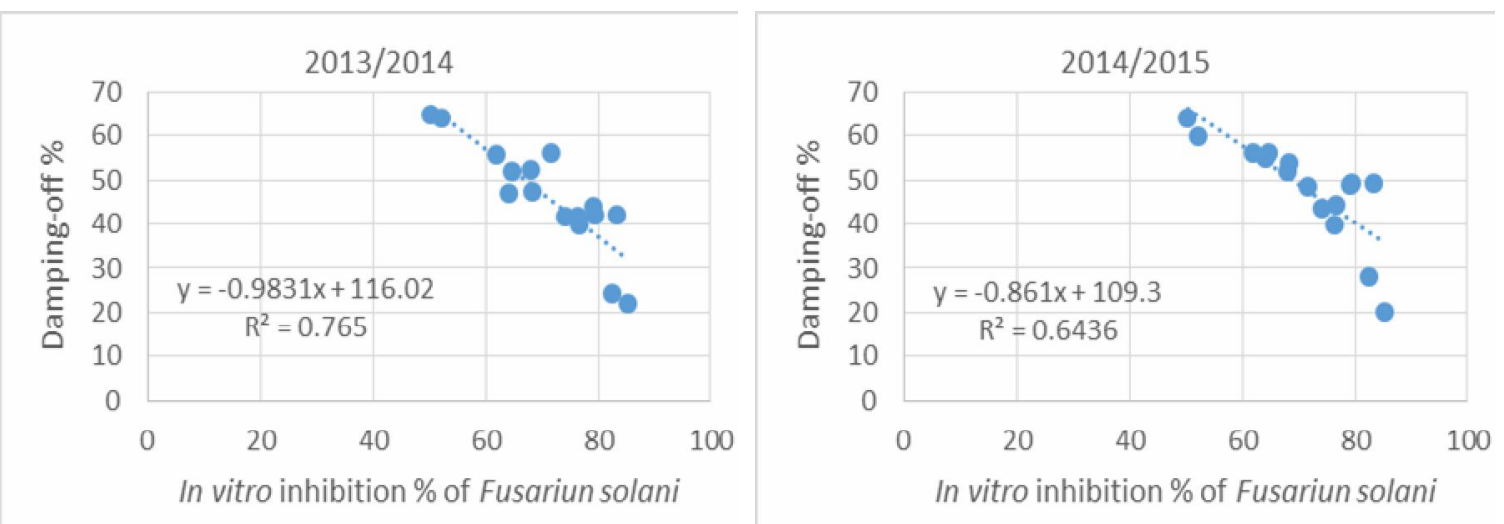

Fig. 1. Correlation between in vitro inhibition $\%$ of $F$. solani and damping-off $\%$ incidence of L. odoratus plants under artificial infection in greenhouse conditions during 2013/2013 and 2014/2015 seasons as affected by different extracts of both $S$. molle and $S$. terebinthifolius leaves and stems

\section{Discussion}

In the present study, three fungal isolates obtained from naturally diseased Lathyrus odoratus showing damping off symptoms were identi- fied as $F$. solani, which is one of main causal pathogen of damping-off in sweet pea and other Leguminosae family (Burnchara and Camacho, 2000; El-Mougy, 2001). In vitro test for antifungal activity of the plant ex- 
tracts on radial growth of $F$. solani revealed that inhibition percentage of $F$. solani growth compared with control significantly varied according to the extract source (leaves or stems) and solvent type. The potential antifungal activity of ethanol leaf extracts appeared highly significant, regardless of the plant species, where inhibition percentage reached more than $80 \%$. On the other hand, acetone seemed effective when used with stems recording $79 \%$ growth inhibition. When the same extracts were assayed for their effect on dampingoff incidence under artificial infection of L. odoratus in greenhouse conditions, almost the same general trend was obtained where ethanol leaf extracts and acetone stem extracts resulted in the least incidence of damping-off. This fact is further supported by the significant negative correlation between in vitro inhibition percentage of $F$. solani and the field incidence of damping-off in L. odoratus plants. Antifungal activity of aqueous and methanolic extracts of $S$. molle and $S$. terebenthefolius trees was previously reported against $F$. solani (Rhouma et al., 2009). Unlike the results of the current experiment, they found that aqueous and methanolic extracts showed a high level of antifungal and antibacterial activity compared to ethanolic extracts.

Most of the published work on both $S$. molle and $S$. terebenthefolius plants focus on the identification of compounds found in the essential oils and their biological activity. It is necessary to explore phytochemical and biological properties of extracts from different parts of both plants species, which initiated the idea of this ex- periment. According to the results of the current experiment, presence of alkaloid, phenolics, flavonoids, and tannins was confirmed in leaves and stems of both plant species. These results are in accordance with the findings of Rhouma et al. (2009) and Carvalho et al. (2013). In addition, presence of such compounds was a good indication for their potential antifungal activity as shown by several researchers such as Johann et al. (2010). In the current study, the detected antifungal effect of the tested extracts could be attributed to their major phytochemical components. Among them, tannins have proved biologically active as antibacterial and antifungal due to their complication with metal ions and macromolecules in addition to their antioxidant effect (Scalbert, 1991). Besides, Taguri et al. (2004) attributed the antimicrobial action to the astringent nature of the phenolic constituents including tannins and other polyphenols present in the extracts.

According to our results, ethanol and acetone, followed by methanol gave appreciable results which could be explained upon the ability of them to enhance the extraction of a large quantity of secondary metabolites due to their polarity, concentration or nature (Tekwu et al., 2012). The plant methanol extract was found to be a potent antibacterial and antifungal agent by many authors such as Rhouma et al., (2009) and Malla et al. (2014). Other groups such as alkaloids, flavonoids and phenols are important in the defense mechanisms of the plant against microbial pathogens (Calixto et al., 2001). These results suggest that extracts from $S$. molle 
and S. terebenthefolius, especially ethanol leaf extracts and acetone stem extracts, are promising naturally derived antifungal compounds against phytopathogenic fungi.

\section{References}

Abdul-Hafeez, E.Y., Mahmoud, A.F., Ibrahim, O.H.M., 2015. Antibacterial Activities and Phytochemical Screening of Alhagi pseudalhagi. Assiut J. Agric. Sci. 46 (5), 33-47.

Abo-Elyousr, K.A.M., Hashem, M., Ali, E., 2009. Integrated control of cotton root rot disease by mixing fungal biocontrol agents and resistance inducers. Crop Protection 28, 295-301.

Barnett, H.L., Hunter, B.B., 1986. Illustrated genera of imperfect fungi. $4^{\text {th }}$ Ed., Macmillan Publishing Co., New York.

Burnchara, R.A., Camacho, L., 2000. Common bean reaction to Fusarium oxysporum f. sp. phaseoli, the cause of severe vascular wilt in central Africa. J. Phytopathol. 148, 39-45.

Calixto, J. B., Scheidt, C., Otuki, M. F., Santos, A. R. S., 2001. Biological Activity of plants extracts: novel analgesic drugs. Expert Opinion in Emerging Drugs 6, 621- 79 .

Carvalho, M.G., Melo, A.G.N., Aragão, C.F.S., Raffin, F.N.2, Moura, T.F.A.L., 2013. Schinus terebinthifolius Raddi: chemical composition, biological properties and toxicity. Rev. Bras. Pl. Med., Botucatu 15 (1), 158-169.

El-Mougy, N.S., 2001. Field application of certain biological and chemical approaches for controlling bean wilt disease.
Egypt. J. Phytopathol. 29, 6978.

El-Mougy, S.N., Nadia, G.E., Abdelkader, M.M., 2007. Control of wilt and root rot incidence In phaseolus vulgaris 1. By some Plant volatile compounds. J. Plant Protect. Res. 47, 255-265.

Evans, W.C., 2002. Trease and Evans' Pharmacognosy, WB Saunders." 15 edn. Edinburgh, London.

Gomez, K.A., Gomez, A.A., 1984. Statistical procedures for Agricultural Research. A. Lviley. Interscience Publication. New York, Pp.678.

Harborne, J.B., 1998. Phytochemical Methods. Chapman Hall, London, England.

Ibrahim, O.H.M., Abdul-Hafeez, E.Y., Mahmoud, A.F., 2015. Antimicrobial and Antioxidant Activities of Stem Bark Extracts of Different Ornamental Trees. Assiut J. Agric. Sci. 46 (5), 1932.

Imamura, Y.. Kuno, K., Kohroki, H., Nakamura, K., Jinkawa, T., 2008. Fusarium wilt of sweet pea caused by Fusarium oxysporum in Miyazaki, Japan. Kyushu Plant Protection Research 54, 30-38.

Johann, S., SÁ, N. P., lima, L. A., Cisalpino, P. S., Cota, B. B., Alves, T. M., Siqueira, E. P., Zani, C. L., 2010. Antifungal activity of schinol and a new biphenyl compound isolated from Schinus terebinthifolius against the pathogenic fungus Paracoccidioides brasiliensis. Annals of Clinical Microbiology and Antimicrobials 9, 30-35. 
Khandelwal, K., 2001. Practical Pharmacognosy-Techniques and Experiments. Nirali Publication, Parkashan.

Kokate, CK., 1994. Practical Pharmacognosy. Vallabh Prakashan, New Delhi, India.

Malla, S., Shrotri, C.K., Jain, R., 2014. Antimicrobial, phytochemical and antioxidant screening of leaves and stem bark from albizia lebbeck. Int. J Pharm Bio Sci 5, 259 - 270.

Mecteau, M.R., Arul, J. Tweddell, R.J., 2002. Effect of organic and inorganic salts on the growth and development of Fusarium sambucinum, a causal agent of potato dry rot. Mycological Research 106, 688-696.

Mezeal, I.A., 2014. Study biocontrol efficacy of pseudomonas fluorescens and bacillus subtilis against Rhizoctonia solani and Fusarium oxysporum causing disease in tomato (Lycopersicon esculentum 1.). Indian Journal of Fundamental and Applied Life Sciences 4 (4), 175-183.

Nakamura, K., Hino, H., Gunji, S., Hattanda, N., Murata, T., Tominaga, H., Fukumoto, K., Akashi, R., 2008. 'Mimi' Sweet Pea for Forcing Culture. HortScience 43 (7), 2238-2239.

Punja, Z. K., Carter, J. D., Campbell, G. M. and Rossell, E. L. 1986. Effects of calcium and nitrogen fertilizers, fungicides, and tillage practices on incidence of Sclerotium rolfsii on processing carrots (Daucus carota). Plant Disease 70, 819-824.

Rhouma A., Ben Daoud, H., Ghanmi, S., ben Salah, H., Romdhane,
M., Demak, M., 2009. Antimicrobial activities of leaf extracts of Pistacia and Schinus species against some plant pathogenic fungi and bacteria. Journal of Plant Pathology 91 (2), 339-345.

Scalbert, A., 1991. Antimicrobial properties of tannins. Phytochemistry $30,3875-83$.

Taguri, T., Tanaka, T., Kouno, I., 2004. Antimicrobial activity of 10 different plant polyphenols against bacteria causing foodborne disease. Biological and Pharmaceutical Bulletin 27, 1965-1969.

Taubenhaus, J.J., 1914. The diseases of the Sweet Pea. PhD Thesis, University of Pennsylvania.

Taylor, L., 2005. The Healing Power of Rainforest Herbs. A Guide to Understanding and Using Herbal Medicinals. Square One Publishers, New York.

Tekwu, E.M., Pieme, A.C., Beng, V.P., 2012. Investigations of antimi-crobial activity of some Came-roonian medicinal plant extracts against bacteria and yeast with gastrointestinal relevance. Journal of Ethnopharmacology142, 265-273.

Tepe, B., Donmez, E., Unlu, M., Candan, F., Daferera, D., Vardar-Unlu, G., 2004. Antimicrobial and antioxidative activities of the essential oils and methanol extracts of Salvia cryptantha (Montbret et Aucher ex Benth.) and Salvia multicaulis (Vahl). Food Chemistry 84, 519-525. 
تأثير مستخلصات من نباتي الفلقل الرفيع والفلفل العريض على مرض موت البادرا ت في بسلة الزهور

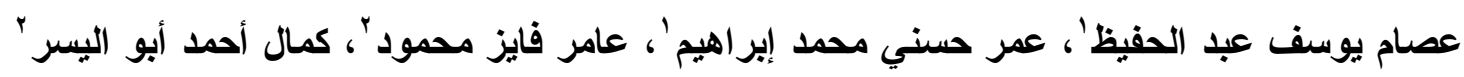

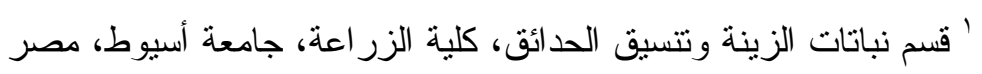

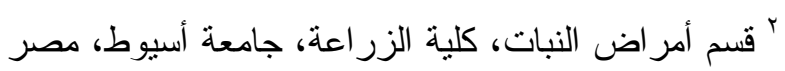

تهدف الدراسة الحالية إلى تقييم التأثير المحتمل لمستخلصات الأوراق و السيقان من نباتي الفلفل الرفيع و الفلفل العريض ضد فطر الفيوزاريوم Fusarium solani فى المعمل وتحت ظروف الصوبة وكذلك إجراء الاختبار ات المبدئية للمحتوى الفيتوكيميائي لكلا النوعين النباتيين. نم تجهيز المستخلصات باستخدام مذيبات مختلفة وهي الماء والايثانول و الميثانول و الأسينون. كما نم عزل سلالة الفيوز اريوم وتعريفها من نباتات بسلة الزهور المصابة طبيعيا بمشتل نباتات

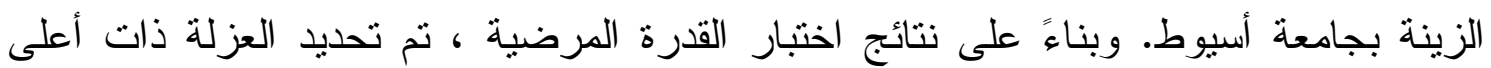

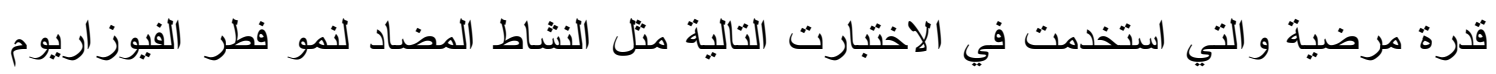

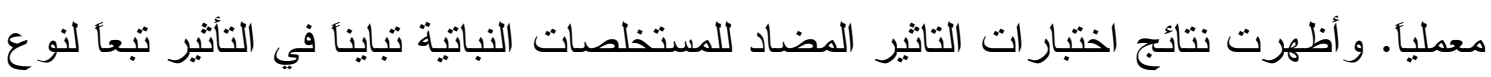

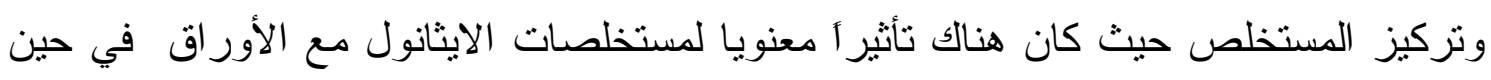
أظهر الأسيتون فاعلية واضحة عند استخدامه مع السيقان، وذللك بغض النظر عن النوع النيات النباتي. كما تم تسجيل أعلى فاعلية مثبطة لنمو الفطر معمليا عند المعاملة بمستخلصات الايثانول و الماء ونهاء

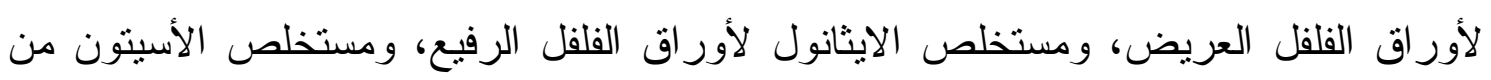

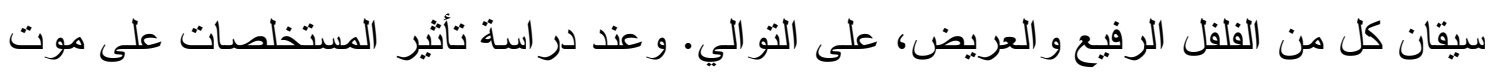
البادرات في نباتات بسلة الزهور تحت ظروف العدوى الصناعية في الصوبة، أظهرت النتائج

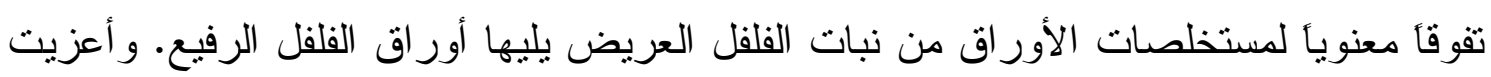
تلك النتائج لمحتوى الأوراق و السيقان لكلا النباتين من القلويدات و الفينو لات و الفلافونيدات

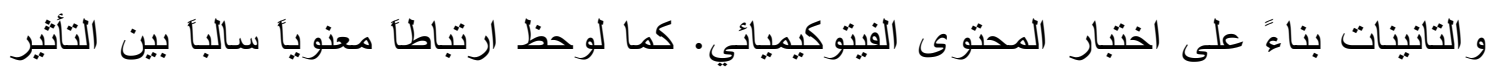

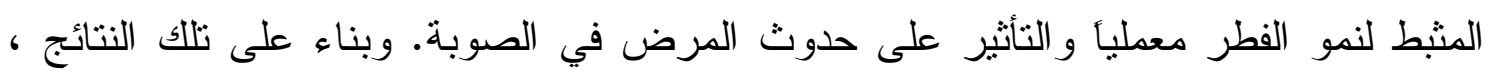
يمكن التوصية بفاعلية مستخلصات نباتي الفلفل الرفيع والعريض ، وخلياصة وضئ مستخلصات

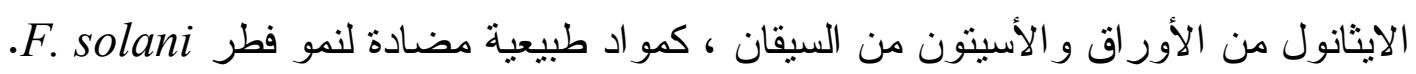


